\author{
Agnieszka Gajewska \\ Instytut Filologii Polskiej, Uniwersytet im. Adama Mickiewicza w Poznaniu
}

\title{
Perwersje archiwum
}

Ślady przeszłości zdeponowane w archiwum budzą nadzieję, że z zasznurowanych teczek i opuszczonych muzeów wydobędziemy głos tych, którzy zostali wykluczeni i zmarginalizowani w dyskusjach historycznych. Niezależnie jednak od intencji poszukiwaczy i poszukiwaczek indywidualnych świadectw z przeszłości, biorąc do ręki dokumenty, zdjęcia i przedmioty, wikłają się oni w pełne napięcia relacje między ofiarami, ocalałymi, beneficjentami i sprawcami [por. Mossa 2011: 664-669]. Mimo to w dyskusjach o archiwach pojawiają się głosy podważające znaczenie doświadczeń badaczy i badaczek. Na przykład Danuta Ulicka [2010: 161], pisząc o zwrocie archiwalnym, podkreślała, że „archiwa nie zapewniają wiedzy niezbitej («faktów»), pozostawily bowiem to, co pozostawić z różnych względów zechciały, a i udostępniają to, co zechcą, niekiedy na mocy prywatnego widzimisię kustosza”. Personifikacja archiwum oraz figura nieliczącego się z niczym jego opiekuna świadczą zapewne o ironicznym stosunku badaczki do próby skonstruowania spójnej teorii dla właśnie wymyślonego, kolejnego zwrotu w humanistyce. Mimo tego dystansu Ulicka uważa, że najbardziej wartościowa jest „lektura prześwietlająca 
dokument jako wypowiedź kulturową”. Badaczka drwi ze zwierzeń naukowczyń i naukowców o niekompletności archiwów oraz anegdot dotyczących problemów z uzyskaniem dostępu do dokumentów i zaleca traktowanie tych ostatnich $\mathrm{z}$ uwzględnieniem ich „ukształtowania językowego”. W tym ujęciu liczy się więc wyłącznie efekt końcowy, czyli odnaleziony dokument. Oznacza to, że złożone uczucia i osobiste historie badaczy i badaczek pozostają, według Ulickiej, bez wpływu na wyniki badań archiwalnych; istotne jest natomiast zwrócenie uwagi na idiolekt twórcy, stylistykę i gatunek [Ulicka 2010: 161].

Postawa badawcza Ulickiej budzi szereg pytań, jeśli odniesie się ją do codzienności pracy w archiwum oraz prób uspójnienia w narracji badawczej rozproszonych informacji. Co stanie się, jeśli badacz przejmie rolę kustosza i ukryje dokument, który mógłby zakwestionować jego ustalenia? Jak wyśledzimy wyprzedawanie oryginałów dokumentów, jeśli od razu założymy, że archiwa są niekompletne? Czy dla badaczy i badaczek inspirowanych rodzinną historią stylistyka odnalezionego dokumentu naprawdę może pozostać najistotniejsza? Za tymi pytaniami kryją się konkretne historie, ciągnące się za mną, odkąd rozpoczęłam badania nad historią rodzinną Stanisława Lema i zagładą Żydów lwowskich. Jak skoncentrować się na idiolekcie funkcjonariusza bezpieki w czytelni Instytutu Pamięci Narodowej, gdy siedząca obok kobieta próbuje ustalić, kto z najbliższej rodziny na nią donosił, i nie potrafi ukryć emocji? Jak czytając pożółkły papier, przestać myśleć o historii opowiedzianej przez archiwistę tłumaczącego mi, że mogę otrzymać wyłącznie kopię dokumentów, gdyż niedawno jeden z odwiedzających czytelnię zjadł dokumenty ze swojej teczki? Jak pracować w korytarzu archiwum Żydowskiego Instytutu Historycznego, gdy za plecami stoją dwie kobiety, które starają się o dokumenty potwierdzające, że teść jednej z nich ratował podczas okupacji Żydów, a głośno dyskutują o tym, że choć robią to w związku z apelem „Gazety Polskiej”, to jednak mają nadzieję, że ich dzieci nigdy się o tym nie dowiedzą? I proszą o kolejne pieczątki, gdyż wystawiony przez pracowników dokument wydaje im się mało przekonujący.

Archiwum rozpatrywane przez pryzmat badaczy i badaczek to nie tyle nieograniczony i z zasady niekompletny zbiór dokumen- 
tów, strzeżony przez anachoretę, ile miejsce spotkań tych, którzy podejmują z nim perwersyjną grę ${ }^{1}$ o to, czyja wersja pamięci zwycięży. W tym ujęciu perwersja to nie rodzaj upodobań seksualnych, ale - jak uczy Jacques Lacan:

[...] identyfikacja ze ślepym, nieugiętym, nieprzebłaganym i kategorycznym automatyzmem karnym, z zamkniętym, doskonale funkcjonującym, nieomylnym systemem, nie powołującym się w swym działaniu na okoliczności przypadkowe, lecz na konieczność własnej zasady. To wreszcie utożsamienie się ze spojrzeniem Innego. [Tymczyszyn 2009: 15]

Perwersyjna gra polega na ascezie i samoograniczeniu, które prowadzą do ekstazy: odkrycia zasłoniętego, sklejenia w całość niewspółmiernych fragmentów, zdobycia wiedzy okupionej cierpieniem. Badacze i badaczki archiwum odnoszą na tym polu utożsamienia się z prawem niewidoczne dla innych sukcesy. Rozkosz badacza i badaczki archiwum okupiona jest przy tym brakiem apetytu, dobrowolnym przebywaniem w budynku opasanym drutem kolczastym i pilnowanym przez uzbrojonych mężczyzn, wdychaniem zarodników grzybów i znoszeniem z uśmiechem impertynencji zatrudnionych tam osób. Ciało w archiwum ma się znacznie gorzej niż ciało w bibliotece, zwłaszcza gdy badania dotyczą okupacji niemieckiej i działalności bezpieki tuż po wojnie. Wiele z przeczytanych dokumentów nie przekłada się na efekty pracy badawczej, mimo to zapamiętane fragmenty opisów zbrodni tkwią w pamięci. Myślę tu o lekturze zeznań żydowskich ofiar, świadczących w obronie zbrodniarzy wojennych, protokołów z historiami ocalałych spisywanych przez urzędników według prostego wzorca, notatek ze spotkań z tajnymi współpracownikami. Wychodząc $\mathrm{z}$ archiwum, ma się być może poczucie rzetelnie wykonanej pracy, polegającej na sprawdzeniu „wszystkiego” i „po kolei”, jednak niejednokrotnie można po niej przełknąć wyłącznie wodę.

1 Posługuję się terminem „perwersja” w kontekście archiwum, uwzględniając jego psychoanalityczne, a nie potoczne znaczenie; podążam więc za koncepcjami Fathimy Moosy [2011] oraz Marca Nichaniana [2009]. 
Na perwersję w badaniach nad ludobójstwem zwracał uwagę Marc Nichanian w The Historiographic Perversion, monografii, w której rozważał konceptualne problemy dotyczące badań nad unicestwieniem na masową skalę ludzi i archiwów. Już we wstępnych rozdziałach swojej książki autor postawił mocną i prowokującą do krytycznej analizy tezę, że ludobójstwo nie jest faktem. Jako przykład posłużyła mu jednak nie zagłada Żydów a ludobójstwo Ormian, które omówił, biorąc pod uwagę prawne, historyczne i artystyczne próby jego przedstawienia. Nichanian zwracał uwagę na polityczne uwikłania badań historycznych. Wskazywał, że także za naukowcami opracowującymi dokumenty stoją interesy państwowe, które wpływają na wyniki badań, w tym na uznanie prawnej odpowiedzialności Turcji za unicestwienie ludności ormiańskiej. Jednocześnie dowodził, że ofiary i ich rodziny także wikłają się w logikę udowadniania i zaprzeczania ludobójstwu i produkują świadectwa, które są pozbawione literackiej formy. Świadkom i ofiarom wydaje się bowiem, że dzięki tej stylistycznej chropowatości przedstawione opisy będą najbardziej zbliżone do zapisu doświadczenia. Ich świadectwa zamieniają się więc w archiwum, a to oznacza, że w toczącej się politycznej grze mogą stać się także dowodem przeciwko ludobójstwu. Nichanian [2009] zwraca więc uwagę na polityczną odpowiedzialność naukowców, artystów i krytyków sztuki, których głos ma prawne konsekwencje, ponieważ ludobójstwo nie jest terminem historycznym, ale właśnie prawniczym [zob. też Leezenberg 2012].

\section{Dokument jako rzecz sama w sobie}

Wśród instytucji gromadzących dokumenty w Polsce dreszcz emocji niewątpliwie wywołuje IPN. To właśnie zbiory tej specyficznej instytucji archiwalnej budziły największą ekscytację w recepcji mojej monografii poświęconej Lemowi. Tymczasem trafiłam tam, ponieważ jedna z pracowniczek żıH-u uświadomiła mi, że to IPN przechowuje materiały z procesów sądowych zbrodniarzy wojennych (Instytut gromadzi dokumenty powstałe od 22 lipca 1944 roku). Podczas dyskusji z redaktorem Wojciechem Orlińskim o pisanych przez nas książkach uświadomiłam sobie, że moja 
decyzja o przekroczeniu progu IPN-u jest decyzją polityczną. Rzeczywiście, to wokół niej toczyła się dyskusja prawicowych publicystów, których zelektryzowała informacja o „teczce” inwigilowanego Lema, mimo że napisałam, iż trudno znaleźć w niej coś interesującego. Ostatecznie zrezygnowałam z cytowania i wykorzystania materiałów pochodzących z podsłuchów i zebranych w czasie inwigilacji. Przyczyną była niedbałość produkowanych przez funkcjonariuszy dokumentów, które budziły wiele moich zastrzeżeń, natomiast pracownicy archiwum w niewielkim stopniu byli w stanie jednoznacznie określić kontekst powstania i wykorzystania dokumentu. Niemniej nie mogę zapomnieć, że te dokumenty przeczytałam i zapamiętałam, co na pewno nie pozostało bez znaczenia dla moich ustaleń.

Marcin Napiórkowski [2011: 14] w artykule Prawda archiwów podkreślat, że IPN „jest bez wątpienia instytucją współczesnego życia politycznego, w szczególny sposób ufundowaną na odniesieniu do kategorii prawdy". Badacz zwracał uwagę, że na plan pierwszy w przypadku IPN-u wysuwają się jego działania śledcze i lustracyjne [Napiórkowski 2011: 16], co oczywiście ma znaczenie, gdy przegląda się teczki tworzone właśnie na potrzeby toczących się śledztw. W przypadku moich poszukiwań była to teczka zebrana dla prokuratorów wyjaśniających sprawę pogromu kieleckiego. Napiórkowski opisał paradoks związany z funkcjonowaniem IPN-u, który nie orzeka o treści dokumentu, tylko stwierdza jego istnienie. Tym samym przechowuje i udostępnia także „dane nieprawdziwe" i nie usuwa ich ze swoich zbiorów. Na prośbę zainteresowanych może je ewentualnie opatrzyć stosowną adnotacją [Napiórkowski 2011: 17]. „IPN [zauważa badacz - A.G.] stanowi klasyczny przykład myślenia za pomocą rzeczy, które zarazem podszywa się pod myślenie za pomocą słów i jego «obiektywne» kategorie prawdy" [Napiórkowski 2011: 19]. W tym ujęciu IPN staje się dla autora interesującym przykładem kulturowych przemian w myśleniu o archiwum:

[...] archiwa nie przechowują ani nie produkują „prawdy”, lecz generują i gromadzą nasze pragnienie jej poznania. Prawda archiwów zbliżałaby się wówczas do prawdy mitu, okazując 
się odpowiedzią na potrzebę doświadczania świata jako sensownego. [Napiórkowski 2011: 25]

W tym kontekście na plan pierwszy wysuwają się oczekiwania badaczek i badaczy oraz towarzysząca im chęć uspójnienia czyjejś historii prywatnej i rodzinnej.

\section{Badacze i badaczki}

Numer „Czasu Kultury” zredagowany przez Lucynę Marzec, zatytułowany Archiwa prywatne, w szerokiej perspektywie obrazuje złożony konglomerat osobistych historii oraz wzajemne uwikłania wielu osób połączonych jedynie pozostawioną przez kogoś mniej lub bardziej spójną spuścizną. Autorzy artykułów ukazują archiwum jako miejsce osobistych spotkań ze spadkobiercami, innymi badaczami oraz bezużytecznymi artefaktami, a wiele z omawianych przez nich odkryć ma znaczenie wyłącznie dla kilku zaangażowanych w opisywaną historię osób. Struktura wstępu redaktorki odsłania, że opowieści o archiwach prywatnych mają charakter nieciągły, akcydentalny, rapsodyczny, a zaangażowanie emocjonalne w badane archiwum rzutuje na sposób ujmowania analizowanego materiału [Marzec 2017].

Proces rozpoznawania własnej historii w badanych dokumentach i zdeponowanych w archiwach relacjach osobistych w interesujący sposób pokazują badaczki archiwów apartheidu. Nie bez znaczenia jest przy tym fakt, że w okresie prześladowań rasowych udzielały one pomocy psychologicznej ofiarom przemocy państwowej, ufundowanej na zasadzie „odseparowani lecz równi”. Fatima Moosa w artykule In the Apartheid Archives. From Perversion to Paradox wskazuje, w jaki sposób analizowane przez nią dokumenty sprawiają, że przypomina się jej własna historia. To właśnie w tych osobistych relacjach udaje się jej uchwycić coś, co za Straker nazywa „drobnym apartheidem”, czyli codziennymi doświadczeniami dyskryminacji, wymykającymi się badaniom kategorii rasowych. Chodzi o uczestniczenie w subtelnej i niesubtelnej wymianie, w której rozpoznać można zarówno akceptację i tolerancję, jak i odrzucenie [Moosa 2011: 665-666]. Jednocześnie 
w badaniach przeszłości, na które nakładają się własne wspomnienia, Moosa dostrzega perwersyjną moc nostalgii. Polega ona na przywiązywaniu wagi do niektórych dokumentów, np. ona sama pieczołowicie przechowuje dokument, dzięki któremu uzyskała specjalną koncesję umożliwiająca jej studia na białym uniwersytecie, czyli instytucji apartheidu.

Być może [podkreśla badaczka - A.G] pragnienie utrzymania takich „pamiątek” odzwierciedla potrzebę potwierdzenia przetrwania w niewyobrażalnie traumatycznym czasie lub po prostu odzwierciedla potrzebę zasygnalizowania, że ktoś był świadkiem decydującej chwili historycznej. [Mossa 2011: 667]

Warto zwrócić uwagę na ten aspekt badań archiwalnych także dlatego, że wiąże się on z fetyszyzmem historycznym i archiwalnym. Przekraczając próg archiwum lub łącząc się z archiwum ze swojego domu, nie liczymy przecież na to, że spędzimy tam kilkadziesiąt godzin, czytając nudne sprawozdania z zebrań lub nieinteresujące listy. Z perspektywy badawczej dobrze byłoby jednak odnaleźć dokumentację prześladowań, właściwie im straszniejszą, tym lepiej. Tymczasem znajdujemy tam raczej coś, co, idąc za koncepcją Straker i Moosy, można by nazwać „drobnym prześladowaniem”, które jest przytłaczające, jeśli chodzi o liczbę dokumentów, jednak trudno je przekonująco opisać. Analiza językowa tych tekstów nie przekłada się na silny argument retoryczny, odnoszący się do wielkiej historii i polityki, choć niewątpliwie stanowi jej odbicie. Poszukując mocnych dokumentów (zwłaszcza w badaniu biografii osób należących do mniejszości), przesuwamy nieuchronnie własne zainteresowania na dokumenty instytucji przemocowych (co zresztą zostało aż nadto dobrze opisane [por. Aldrich, reż. 2009]). Tymczasem nuda archiwów może zmusić nas do tropienia bardziej subtelnych form wzajemnych zależności. Straker wspomina np. o tym, że badając archiwa, mogła przeanalizować także własny udział w przemocy rasowej poprzez badanie „apartheidu umysłu” i „rasizacji umysłu w sferze intymnej” [Moosa 2011: 667-668]. Codzienne praktyki wymuszające kontakt $\mathrm{z}$ instytucjami przemocowymi, organizacja przestrzeni 
prywatnej, sposób przedstawiania rasowej przemocy poprzez klisze, reprodukcje i kino wywierają bowiem silny nacisk na wyobrażenia o przeszłości, często wypierając i unieważniając świadectwa i świadków/ofiary.

\section{Autor Solaris}

Badacze i badaczki archiwów znajdują się więc w klinczu między upolitycznieniem ich badań a własnym zaangażowaniem w reprodukowanie klisz i stereotypowych ujęć. Wywołuje to silne emocje, zwłaszcza kiedy wiąże się z koniecznością pisania o zbrodniach. Jeden $\mathrm{z}$ aspektów tygla afektów towarzyszących osobom badającym historie wojennych mordów opisał Martin Pollack [2014: 78] w zbiorze esejów Skażone krajobrazy:

Fotografie zamordowanych - którzy często na wpół albo całkowicie rozebrani, okaleczeni, bezbronni, rzuceni jedni na drugich, niedbale niczym nieprzydatne przedmioty, leżą tak wystawieni na nasze bezwstydne spojrzenia - mają w sobie coś z pornografii. Gdy na nie patrzymy, czujemy odrazę i obrzydzenie, przerażenie i litość, jednocześnie jednak pewne podniecenie, jakby przyłapano nas na czymś zakazanym. Sami sobie wydajemy się podglądaczami, którzy pozbawiają godności nieznanych zmarłych, gdy oni, nie mogąc się przed tym obronić, wystawieni są na naszą ciekawość w najbardziej intymnej i całkowicie prywatnej chwili śmierci. Jako część anonimowego stosu ciał, w którym trudno odróżnić poszczególne twarze.

Biorąc pod uwagę ostrzeżenia Pollacka, Straker i Nichaniana, chciałabym zastanowić się nad tym pornograficznym aspektem przedstawiania śmierci i scen upokorzenia w kontekście dokumentalnego, biograficznego filmu o Stanisławie Lemie zatytułowanego Autor Solaris (2016) w reżyserii Borysa Lankosza, do którego scenariusz napisał Orliński. W opisie festiwalowym producentów filmu podkreślono, że jest to „kreacyjny dokument”, złożony z ,archiwalnych kolaży, inscenizacji oraz unikalnych frag- 
mentów wywiadów" [Autor Solaris 2018]. W tej analizie interesują mnie zwłaszcza aspekty perwersyjnej historiografii, politycznego aspektu dyskusji o ludobójstwie, wizualnych przedstawień ofiar i sprawców oraz unieważnienie głosu ofiary. Charakterystycznym rysem tego filmu jest połączenie informacji z autobiograficznego eseju Lema Wysoki Zamek i wywiadu telewizyjnego ze zdjęciami $\mathrm{z}$ archiwum telewizji i rekonstrukcjami historycznymi. Rekonstrukcja sceny pogromu, którego ofiarą był Lem, została zaczerpnięta z powieści Głos Pana, w której pisarz złożył świadectwo dotyczące własnych przeżyć. W książce jednak rozbił tę narrację na dwa głosy, co obrazuje wewnętrzne pęknięcie protagonisty. Wyreżyserowana przez Lankosza scena rozstrzeliwania pracujących przy usuwaniu zwłok Żydów korzysta z estetyki, do której przyzwyczaiły nas filmy dokumentalne ввС, w dodatku rozmywa dalszy plan akcji. Ofiary pogromu, przez wiele godzin pracujące przy wynoszeniu rozstrzelanych i skatowanych ciał, nierzadko w stanie daleko posuniętego rozkładu, stoją w wersji filmowej ubrane w czyste sukienki i wełniane ubrania, bez śladów bicia, szarpania i zalewającej oczy i ręce krwi. Sceny śmierci rozstrzeliwanych ofiar znajdują się poza kadrem, co oddaje perspektywę opisywaną w powieści. Kluczową sceną rekonstrukcji jest ta, w której niemiecki oficer wzywa stłoczone ofiary, by jedna z nich wystąpiła na ochotnika. Pojawia się więc reżyserska sugestia, że właśnie Lem wykazał się tą odwagą. Jednak sam Lem [2013: 112] - a analizujemy przecież film biograficzny - pisał w liście do Michaela Kandla, że „oprócz tego dodatku o wywołaniu ochotnika wszystko się zgadza....J Jednocześnie w narracji Lema oraz złożonych przez niego świadectwach nie ma wzmianki o mordowaniu kobiet, a właśnie sceny z udziałem dwóch pięknych, dobrze ubranych postaci kobiecych są w tej rekonstrukcji kluczowe. W dodatku jedna $\mathrm{z}$ nich ginie na oczach narratora, który ma przedstawić perspektywę Lema. Na marginesie, nie sposób nie zauważyć, że na filmie archiwalnym z pogromu w Brygidkach kobiety z czarnymi chustami na głowach zostały odseparowane od mężczyzn i pracowały przy oczyszczaniu zwłok. Trudno więc sobie wyobrazić, że później można je było stawiać razem z mężczyznami w plutonie egzekucyjnym. Oczywiście było to możliwe, jednak interesujące jest przeniesienie uwagi 
z protagonisty-Lema na wymalowaną kobietę o jasnych włosach, która kieruje wzrok prosto w obiektyw.

Scena rekonstrukcji pogromu zestawiona została $\mathrm{z}$ wypowiedziami Timoty’ego Snydera w języku angielskim. Badacz wyjaśnia, komentując lincze mieszkańców Lwowa dokonywane na żydowskich ofiarach, z jakich powodów niemieccy żołnierze kręcili filmy propagandowe i dlaczego miały one antysemicki i rasistowski charakter. Komentarz Snydera do rekonstrukcji Lankosza wydaje się częściowo nieadekwatny, i to nie z winy historyka. W rekonstrukcji zachowano czytelny podział na Żydów - ofiary i Niemców - oprawców, choć na filmie archiwalnym niemieccy żołnierze pojawiają się jedynie w tle, a plecy żydowskich sąsiadów pałkami okładają osoby bez mundurów - ukraińscy i polscy mieszkańcy Lwowa.

Wypowiedzi Snydera towarzyszą kadry z fabularnego filmu W ciemności w reżyserii Agnieszki Holland oraz z późniejszego o kilka tygodni pogromu. Przedstawiają biegnące, nagie kobiety i jednego nagiego mężczyznę. Kadry propagandowego niemieckiego filmu skupiają się na korpusie, ukazując ciało od szyi do kolan. Ten ewidentnie pornograficzny fragmentu filmu nakręconego przez niemieckich żołnierzy ma niewiele wspólnego z pogromem w Brygidkach, gdzie przy usuwaniu ciał ofiar NKWD zmuszony siłą pracował Lem - bohater filmowej narracji w tle. W filmie kręconym w Brygidkach kadry także obejmują kobiety, jednak są one ubrane w długie suknie, a kilka $\mathrm{z}$ nich ma chusty na głowach. W dodatku, mimo trwającej dookoła nich przemocy, starają się jak najdelikatniej usuwać miotełkami brud z wyciąganych z podziemi ciał. Ich ostrożność, oprócz szacunku do zwłok, związana była także z tym, że wśród zabitych mogły odnaleźć bliskie osoby, ponieważ Żydzi także byli więzieni przez NKWD. Kontrast między tymi dwiema scenami kręconymi przez sprawców nie zmienia faktu, że obserwujemy tę scenę z perspektywy inicjatorów i nadzorców pogromu. Kadry z biegnącymi, nagimi kobietami w filmie Lankosza przypominają przy tym wielokrotnie powielane i omawiane zdjęcie wykonane przez Alberto Israela Errerę, członka Sonderkomando w Auschiwtz-Birkenau.

Wszystko to prowokuje do zadawania wielu pytań. Po pierwsze: dlaczego to lincz kobiet ma za zadanie zilustrować przemoc 
wobec Lema? Po drugie: co sprawiło, że z kadrów rekonstrukcji historycznej znikają ukraińscy i polscy pomocnicy niemieckich żołnierzy, choć w początkowych kadrach widzimy ukraińską flagę? Po trzecie: dlaczego o pogromie we Lwowie opowiada się kliszami zaczerpniętymi z wizualnych reprezentacji Auschwitz-Birkenau? Po czwarte i ostatnie (choć pytań nasuwa się więcej): na ile rekonstrukcje historyczne zastępują filmy archiwalne i wprowadzają zmiany w układzie sił między ofiarami a sprawcami, dodając przy tym retusz estetyczny? Te pytania wskazują, że przedstawienia ofiar i punkt wiedzenia świadków nieustannie ulegają przemilczeniu. Są niestosowne, budzą obrzydzenie, ukazują przemoc pozbawioną celu i świat pełen pogardy dla cierpienia.

Kontrast estetyczny między rekonstrukcją historyczną a wykorzystaniem zdjęć archiwalnych wskazuje na tabuizację tematu ludzkiego ciała poddawanego przemocy, mimo że współczesne kino właściwie karmi się scenami masakry. W scenie rekonstrukcji uwaga operatora skupia się na wymianie spojrzeń z zalęknionymi, ale nie przerażonymi kobietami. Sceny rozpaczy toczą się na dalszym planie. Czekający na śmierć nie są zmasakrowani, oblepieni krwią, kałem i rozkładającymi się ciałami. Jeśli taka wizja reżyserska dominuje $\mathrm{w}$ filmie, $\mathrm{z}$ jakich powodów wykorzystane zostały w nim pornograficzne zdjęcia nakręcone przez niemieckich żołnierzy? Oczywiście można w pierwszej chwili pomyśleć o pomyłce. Jednak kadry z pogromu w Brygidkach pojawiają się w filmie Autor Solaris. Sceny grupowe z kobietami zostają z niej jednak wycięte, z wyjątkiem jednej: ukazującej, jak starsza kobieta w białej chustce na głowie (Ukrainka lub Polka) wyrywa kij mężczyźnie i okłada nim żydowską ofiarę. Ten sadystyczny gest również można - idąc za wskazówkami George’a L. Mosse’a z książki Nationalism and Sexuality - rozpatrywać w kategorii budowania erotycznego napięcia widza.

Wizualne przedstawienie zaciera tym samym ślady cierpienia i upokorzenia ofiar. W ten sposób staje się ilustracją do słów Napiórkowskiego, który podkreślał, że archiwa gromadząi generują pragnienie poznania prawdy, przekształcając się mit. Tak potraktowane filmy propagandowe nie zmieniają niczego w postrzeganiu relacji między ofiarami i sprawcami, nie naruszają też równowagi 
w relacjach politycznej odpowiedzialności za pogrom Polaków i Ukraińców. Sadomasochistyczny spektakl rozgrywa się przed oczyma widza, ponieważ film archiwalny potraktowano w nim właśnie jako rzecz samą w sobie, utrwalającą przeszłość. Zupełnie nie poddano natomiast refleksji ani samego materiału, ani celu jego powstania. Propagandowy film zarejestrowany podczas pogromu w Brygidkach miał przecież służyć ukazaniu zbrodni NKwD. Nic więc dziwnego, że koncentruje się na martwych ciałach, śladach po kulach na murze oraz na samosądzie. Nie można na nim ukazać masakry przeprowadzanej $\mathrm{w}$ tym samym czasie przez wykonujących niemieckie rozkazy Polaków i Ukraińców. Jej przykłady znamy z relacji ocalałych, chociażby z obszernego świadectwa Kurta L. Lewina, który w 1946 roku opisał własne doświadczania w książce Przeżyłem: saga świętego Jura. Drugi wykorzystany film ma, w ujęciu niemieckiej propagandy, pokazać brak jakichkolwiek zasad moralnych tłumu lwowskich mieszkańców, a przy okazji obnaża ludzkie ciało, korzystając z ujęć zaczerpniętych z pornograficznych przedstawien.

Film Autor Solaris nie tylko zaciera punkt widzenia świadków i ofiar, ale także eskaluje napięcie emocjonalne poprzez nagie ciała kobiet. Zabijani, obnażeni i bici mężczyźni właściwie znikają z kadru, podobnie jak bijący ich i mordujący Ukraińcy i Polacy. Polityka ingeruje w dobór źródeł, by za dobrze znanym (choć nadal budzącym zarówno współczucie, jak i wrażenia podglądactwa) obrazem nagich ciał kobiet ukryć upokorzenie mężczyzn (które było udziałem Lema) i ominąć temat odpowiedzialności Ukraińców i Polaków za katowanie i mordowanie Żydów. Decyzja, by zilustrować pogrom w Brygidkach kadrami z innego pogromu, $\mathrm{i}$ to wybierając z niego kadry z nagimi ciałami kobiet, jest jednoznaczna z decyzją, by film biograficzny o Lemie nie wywołał skandalu i mógł zostać przyjęty przez międzynarodową publiczność bez wikłania się $\mathrm{w}$ politykę. $\mathrm{Z}$ tego też powodu - w moim przekonaniu - o udziale w pogromie polskich i ukraińskich sąsiadów ofiar opowiada w filmie po angielsku Snyder. Konsekwencją prowadzenia narracji między rafami politycznych sporów jest zatarcie świadectwa, do czego paradoksalnie przyczynia się właśnie wykorzystanie filmów archiwalnych. 


\section{Zakończenie}

Andrzej Leśniak w artykule Goraczka archiwum w sztuce wspótczesnej. Symptomy choroby i propozycja terapii zaznacza, że to nie instytucja archiwum stanowi problem współczesności, a zmiana sposobu myślenia o archiwalności. Archiwum nie jest już wyłącznie przestrzenią pracy badawczej, skoncentrowanej na analizach przeszłości, ale zaczęło być wykorzystywane do prezentacji artystycznych wizji, skupionych na przedstawieniach przepastności archiwum oraz wyrwanych z kontekstu dokumentów. Coraz częściej, podkreśla badacz, artyści i artystki wykazują się przy tym ignorancją i bezczynnością wobec świadectw historycznych [Leśniak 2011: 101]. Leśniak [2011: 103] podkreśla, że w wyniku tych przeobrażeń

archiwum stało się warunkiem możliwości niepamiętania, magicznym słowem kluczem, które nie gwarantuje już historycznego odniesienia, lecz utrudnia dostęp do wiedzy na temat przeszłości. Jeszcze do niedawna wierzyliśmy, że przywiązanie do badań archiwalnych prowadzonych zarówno przez artystów, jak i przez historyków sztuki zagwarantuje nam sukces w walce z kulturową amnezją, teraz jednak potrzebujemy mocniejszych gwarancji.

Sposób wykorzystania dokumentów archiwalnych dotyczących pogromów we Lwowie w filmie Lankosza świadczy o tym, że owa amnezja ogarnia także filmy dokumentalne i biograficzne. Stawka jest jednak wysoka, ponieważ możemy zapomnieć o wydarzeniach z przeszłości, zanim pojmiemy ich znaczenie. Świadectwa ofiar zastąpią nam kadry z filmu kręconego przez sprawców. Po raz kolejny nie usłyszymy więc tego, co mówią świadkowie. A przecież rozpoczęliśmy pracę w archiwum, żeby przedstawić ich perspektywę. 


\section{Bibliografia}

Aldrich Robert, red. (2009), Geje i lesbijki. Życie i kultura, przeł. Piotr Nowakowski, Universitas, Kraków.

Autor Solaris (2018), [online], [dostęp: 15 kwietnia 2019], https://www. filmweb.pl/film/Autor+Solaris-2016-774662/descs.

Leezenberg Michiel (2012), Book reviews: 'The Historiographic Perversion', "Journal of Genocide Research", vol. 14, s. 244-247.

Lem Stanisław (2013), List z 7 grudnia 1972 roku, w: Stanisław Lem, Tomasz Lem, Stawa i fortuna. Listy do Michaela Kandla 1972-1987, przeł. Jerzy Jastrzębski, Wydawnictwo Literackie, Kraków, s. 109-115.

Leśniak Andrzej (2011), Gorączka archiwów w sztuce wspótczesnej.

Symptomy choroby i propozycja terapii, „Kultura Współczesna”, nr 4 (70), s. 100-107.

Marzec Lucyna (2017), W archiwum prywatnym, „Czas Kultury”, nr 2, s. 6-15.

Moosa Fathima (2011), In the Apartheid Archives: From Perversion to Paradox. Commentary on Paper by Gillian Straker, „Psychoanalytic Dialogues", nr 21, s. 664-669.

Mosse George L. (1997), Nationalism and Sexuality: Respectability and Abnormal Sexuality in Modern Europe, Howard Fertig, New York [USA].

Napiórkowski Marcin (2011), Prawda archiwów, „Kultura Współczesna”, $\mathrm{nr}$ 4, s. 12-25.

Nichanian Marc (2009), The Historiographic Perversion, przel. Gil Anidjar, Columbia University Press, New York [USA].

Pollack Martin (2014), Skażone krajobrazy, przeł. Karolina Niedenthal, Wydawnictwo Czarne, Wołowiec.

Tymczyszyn Agata (2009), Jacques Lacan. Pragnienie Innego,

„Psychoterapia”, nr 3 (150), s. 9-19.

Ulicka Danuta (2010), Zwrot archiwalny (jak ja go widzę), „Teksty

Drugie”, nr 1-2, s. 159-164.

Agnieszka Gajewska

\section{Perversions of the archive}

In the article, the author discusses the problematic status of an archival document, taking into account the concepts of perverse historiography and the methodological indicators of the apartheid archive. Documents stored in IPN (Institute of National Remembrance) have been used to show the challenges faced by the people investigating the documents stored there and attempting to unify the material found in the archive. The analysis of 
Autor Solaris, a 2016 biographical documentary film about Stanisław Lem, is preceded by reflections on the involvement of the archive researchers in politics and their reproductions of clichés and stereotypes about the past, which the author sees as directly leading to blurring and erasing of the victims' testimonies. In doing so, the author uses critical analyses of the pornographic aspects of the presentation of mass murder victims. Relating to a concept proposed by one of the critics indicating that using archival sources in modern art leads to a mass amnesia, the author points to the dangers of using Nazi propaganda films in contemporary documentary film.

Keywords: archive; Stanisław Lem; Autor Solaris; perverse historiography; apartheid archive.

Agnieszka Gajewska - doktor habilitowana, profesor UAM, literaturoznawczyni, autorka książek Zagłada i gwiazdy. Przeszłość w prozie Stanistawa Lema (2016) oraz Hasło: feminizm (2008). Redaktorka naukowa antologii przekładów Teorie wywrotowe. Przez jedną kadencję kierowała podyplomowymi gender studies na Uniwersytecie im. Adama Mickiewicza w Poznaniu. Jest dyrektorką Interdyscyplinarnego Centrum Badań Płci Kulturowej i Tożsamości UAM. Adres e-mail: Agnieszka.Gajewska@amu.edu.pl. 
